\title{
Mid-rotation fertilization and liming of Pinus taeda: growth, litter, fine root mass, and elemental composition
}

\author{
William Magrim Adam ${ }^{(1)}$, \\ Valdécio Dos Santos Rodrigues ${ }^{(2)}$, \\ Ederlan Magri (2), \\ Antônio Carlos Motta Vargas ${ }^{(2)}$, \\ Stephen A Prior ${ }^{(3)}$, \\ Leandro Moraes Zambon ${ }^{(4)}$, \\ Rubia Luciane Dominschek Lima ${ }^{(2)}$
}

Forest floor litter can influence biogeochemical cycling and root growth in $\mathrm{Pi}$ nus taeda systems, especially on low soil fertility sites. The impact of fertilization and liming on forest floor litter (quantity, elemental composition and root presence) was evaluated in a Pinus taeda stand in southern Brazil. A nutrient omission experiment was initiated in November 2008 on an 11 year-old Pinus taeda plantation. The experiment was a randomized block design with seven treatments and four blocks. The treatments were: complete (macro + micro + lime); minus macronutrients; minus micronutrients; minus $\mathrm{K}$; minus $\mathrm{Zn}$; minus lime; and control. In 2012, forest floor litter samples were collected, divided by layer (new litter, old litter, coarse fragmented forest layer $>2 \mathrm{~mm}$, fine fragment forest floor $<2 \mathrm{~mm}$, and fine roots) and analyzed for concentrations of $\mathrm{Na}, \mathrm{Al}$, and total nutrients. Results indicated that lime increased $\mathrm{Ca}$ and $\mathrm{Mg}$ concentrations, reduced Al toxicity, and improved fine root growth. An increase in fine roots was observed in treatments without $\mathrm{K}$. There were large increases in $\mathrm{Fe}$ and $\mathrm{Al}$ as a function of litter age and increased $\mathrm{Mn}$ in fragmented litter when lime was applied. There was little variation in forest floor litter accumulation in all treatments. Elemental abundance was $\mathrm{C}>\mathrm{N}>\mathrm{Fe}>\mathrm{P}>$ $\mathrm{Ca}>\mathrm{K}>\mathrm{Mg}>\mathrm{Mn}$ under control conditions and $\mathrm{C}>\mathrm{N}>\mathrm{Ca}>\mathrm{Mg}>\mathrm{P}>\mathrm{Fe}>\mathrm{Mn}>\mathrm{K}$ for the complete treatment. Occurrence of needle chlorosis, similar to that reported for $\mathrm{Mg}$, and low growth under lime omission indicate that $\mathrm{Mg}$ was a major factor limiting growth. Fertilization and liming affected the bio-cycling of nutrients, Al toxicity, and root growth.

\section{Keywords: Nutrient Concentration, Litter, Ca:Al Ratio, Forest Management}

ers regions, nutrient removal by forest harvests can lead to soil nutrient exhaustion (Huntington 2000). Thus, replacing these exported nutrients is essential for maintaining long-term sustainability and yield (Motta et al. 2014). Replenishing pine plantation nutrients via fertilization at mid-rotation has proven more beneficial than initial fertilization (Carlson et al. 2013).

The forest floor is relevant to soil protection and nutrients cycling. This distinctive feature of forest ecosystems is composed of litter (e.g., leaf, branches, bark, etc.) that are in different stages of decomposition above the soil surface. Efforts to preserve or maintain this forest component are critical for ensuring sustainability of forest systems (Motta et al. 2014). Soil fertility can play an important role on forest floor litter mass in pine systems since an inverse relationship between forest floor litter and soil fertility has been reported (Vogel et al. 2015). This relationship might be associated with low residue decay due to low soil microbiological activity and poor nutrient quality of litterfall (Bauhus et al. 2004).

Residue nutrient quality, in terms of total available nutrients and $\mathrm{C}: \mathrm{N}$ ratio, has been shown to be an important parameter in predicting residue decay (Zhang et al. 2008). Nutrients such as $\mathrm{Mn}$ have been shown to affect decay (Berg et al. 2010). In both cases, total nutrients and $\mathrm{Mn}$ can be influenced by fertilizer and lime applications. Pinus spp. is known to generate poor residue with low nutrients and low decomposition rates that result in thick forest floors (Zinn et al. 2002). Sanchez (2001) confirmed that fertilization can accelerate decomposition and can also increase litterfall input.

Enhanced microbial activity due to fertilizer and lime amendment was noted as being responsible for a $70 \%$ reduction in forest floor mass 20 years after application (Jandl et al. 2003). Reductions in forest floor litter have been reported under different conditions by others (Marschner \& Wilczynski 1991, Prietzel et al. 2008). In contrast, Kiser et al. (2013) reported that fertilization had no influence on forest floor decomposition. Other studies have reported no change (Prescott 1995) or increased forest floor mass from fertilization (Prescott et al. 1992). Contrasting effects of liming on forest floor mass were also observed with soil type (Rizvi et al. 2012) and application rate (Persson et al. 1995). Overall, these observations suggest that soil type and amendment rate may be important factors for maintaining forest floor litter and forest sustainability.

Nutrient amendments can be absorbed by roots within forest floor litter and soil (Lopes et al. 2010); these nutrients enter into the forest biocycle (Batista et al. 2015) 
and affect litterfall composition. The influence of fertilization on forest floor composition varies among nutrients, since the rate of nutrient absorption and redistribution (from senescent needles to new tis sue) varies from high for $\mathrm{K}, \mathrm{P}, \mathrm{Cu}$ and $\mathrm{B}$, to very low for $\mathrm{Ca}$ and $\mathrm{Al}$ (Vieira \& Schumacher 2009).

On the other hand, nutrient amendment can directly change the chemical composition of the forest floor when scattered over the litter (Batista et al. 2015). Applied nutrients can be physically bound in forest floor litter and immobilized or adsorbed by organic compounds resulting from different degrees of litter decomposition (Marschner \& Wilczynski 1991, Batista et al. 2015).

The continual process of litterfall deposition and decay creates layers in the forest floor differing in age and chemical composition (Motta et al. 2014). Nutrient concentrations in forest floor layers can have either direct or inverse relationships with residue age and degree of decomposition (Trevisan 1992). Leaching and root absorp tion can result in decreased concentrations while mass loss from decomposition and/ or input from tree canopy litterfall can have an inverse effect. In addition, Fe and Al are major soil constituents that can strongly affect litter composition by direct soil contact and deposition via soil bioturbation (Marschner \& Wilczynski 1991, Rodrigues et al. 2018, Rabel et al. 2020).

The influence of fertilization and liming on forest floor roots has been evaluated under different conditions and in different plant species (Sayer et al. 2006). Fertilization can reduce roots found in forest floor litter (Bakker et al. 2009). This response can vary by applied nutrients, and $\mathrm{K}$ application has been reported to decrease the amount of roots (Yavitt et al. 2011, Sayer et al. 2012). The influence of fertilization and liming on root responses in forest floor litter appears to be complex and few studies have evaluated this aspect under the conditions found in southern Brazil.

The objective of this study was to evaluate the influence of lime and fertilizer application on tree growth, quantity and quality of forest floor litter, as well as impacts on fine root production in an 11-yearold Pinus taeda stand in southern Brazil, where the standard length of the rotation is 22 years.

\section{Materials and methods}

\section{Study site}

The experimental area was located in the Jaguariaíva county $\left(24^{\circ} 18^{\prime} 58.66^{\prime \prime} \mathrm{S}, 49^{\circ} 44^{\prime}\right.$ $15.58^{\prime \prime}$ W), Paraná state, southern Brazil. The regional climate is a transition between Cfa and Cfb (Alvares et al. 2013) with average rainfall varying from 1400 to 1600 $\mathrm{mm} \mathrm{rr}^{-1}$ and an altitude of $1070 \mathrm{~m}$ a.s.l. The soil was classified as a Red-yellow Oxisol and physical and chemical characteristics are shown in Tab. 1.

Soil chemical analysis consisted of: $\mathrm{pH}$ $\mathrm{CaCl}_{2} 0.01 \mathrm{M}$ (1:2.5 - soil:solution ratio), soil buffer to $\mathrm{pH} 7(\mathrm{H}+\mathrm{Al})$, exchangeable $\mathrm{Al}$, $\mathrm{Ca}$, and $\mathrm{Mg}(\mathrm{KCl} 1 \mathrm{M}$ - extraction), available $\mathrm{P}, \mathrm{K}, \mathrm{Fe}, \mathrm{Mn}, \mathrm{Zn}$, and Cu (Mehlich I - extraction), and organic $C$ according to procedures of Marques \& Motta (2003). Soil granulometric analysis of clay, silt, and coarse and fine sand was performed according to Donagema et al. (2011) using the pipette methodology.

\section{Experimental design}

The experiment was a randomized block design with 7 treatments and 4 blocks. Parcels had 16 useful trees spaced $2 \mathrm{~m}$ within rows and $3 \mathrm{~m}$ between rows with two border rows. An 11-year-old pine stand in the second rotation with no history of fertilizing or liming was selected for the experiment. Prior to experimental setup, trees in this area exhibited low growth rates with some visible symptoms of nutri-

Tab. 1 - Soil physical and chemical properties of experimental area before fertilizer and lime application in Paraná state, southern Brazil. (ECEC): Effective cation exchange capacity; (m): Aluminum saturation.

\begin{tabular}{llccccc}
\hline \multirow{2}{*}{ Variable } & \multirow{2}{*}{ Units } & \multicolumn{5}{c}{ Soil layer $(\mathbf{c m})$} \\
\cline { 3 - 7 } & & $\mathbf{0 - 5}$ & $\mathbf{5 - 1 0}$ & $\mathbf{1 0 - 2 0}$ & $\mathbf{2 0 - 4 0}$ & $\mathbf{4 0 - 6 0}$ \\
\hline $\mathrm{pH} \mathrm{CaCl}$ & - & 3.2 & 3.6 & 3.7 & 3.8 & 3.8 \\
\hline $\mathrm{Al}^{3+}$ & $\mathrm{mmol}_{c} \mathrm{dm}^{-3}$ & 30.7 & 21.7 & 18.0 & 15.0 & 13.0 \\
\hline $\mathrm{H}+\mathrm{Al}$ & $\mathrm{mmol}_{c} \mathrm{dm}^{-3}$ & 112.5 & 73.3 & 59.0 & 50.0 & 40.3 \\
\hline $\mathrm{Ca}^{2+}$ & $\mathrm{mmol}_{c} \mathrm{dm}^{-3}$ & 3.5 & 3.5 & 3.5 & 3.3 & 3.5 \\
\hline $\mathrm{Mg}^{2+}$ & $\mathrm{mmol}_{c} \mathrm{dm}^{-3}$ & 1 & 1 & 1 & 1 & 1 \\
\hline $\mathrm{K}^{+}$ & $\mathrm{mmol}_{c} \mathrm{dm}^{-3}$ & 0.63 & 0.45 & 0.38 & 0.40 & 0.35 \\
\hline $\mathrm{Na}^{+}$ & $\mathrm{mmol}_{c} \mathrm{dm}^{-3}$ & 0.2 & 0.1 & 0.1 & 0.2 & 0.1 \\
\hline $\mathrm{ECEC}$ & $\mathrm{mmol}_{c} \mathrm{dm}^{-3}$ & 35.98 & 26.75 & 22.93 & 19.73 & 17.90 \\
\hline $\mathrm{m}$ & $\%$ & 85 & 81 & 79 & 76 & 73 \\
\hline $\mathrm{P}$ & $\mathrm{mg} \mathrm{dm}^{-3}$ & 3.8 & 3.7 & 1.4 & 1.5 & 1.2 \\
\hline Sand & $\mathrm{g} \mathrm{kg}^{-1}$ & 753 & 771 & 794 & 779 & 747 \\
\hline $\mathrm{Clay}$ & $\mathrm{g} \mathrm{kg}^{-1}$ & 133 & 140 & 153 & 138 & 140 \\
\hline
\end{tabular}

ent deficiency. Using the omission diagnosis technique, treatments were manually applied in November 2008 and in January 2010. The amount of nutrients applied per year were: $40 \mathrm{~kg} \mathrm{ha}^{-1}$ of $\mathrm{N}$ (urea); $60 \mathrm{~kg} \mathrm{ha}^{-1}$ of $\mathrm{P}_{2} \mathrm{O}_{5}$ (triple super phosphate); $80 \mathrm{~kg} \mathrm{ha-1}$ of $\mathrm{K}_{2} \mathrm{O}$ (as potassium chloride); $3.0 \mathrm{~kg} \mathrm{ha}^{-1}$ of Zn (zinc sulfate); $2.0 \mathrm{~kg} \mathrm{ha}^{-1}$ of B (as ulexite); $1.5 \mathrm{~kg} \mathrm{ha}^{-1}$ of $\mathrm{Cu}$ (cooper sulfate); and $20 \mathrm{~g} \mathrm{ha}^{-1}$ of Mo (sodium molybdate). Additionally, lime with a total neutralizing power of $89.4 \%$ was applied as a $\mathrm{Ca}$ and $\mathrm{Mg}$ source at $1.300 \mathrm{~kg} \mathrm{ha}^{-1}(28.9 \%$ and $20.6 \%$ of $\mathrm{CaO}$ and $\mathrm{Ca}$, respectively; $19.9 \%$ and $11.9 \%$ of $\mathrm{MgO}$ and $\mathrm{Mg}$, respectively). Lime was manually applied over the litter surface, followed by other nutrient applications on the same day. The treatments were: $\mathrm{T} 1$, complete; T2, minus macronutrients; T3, minus micronutrients; $\mathrm{T} 4$, minus $\mathrm{K}$; $\mathrm{T} 5$, minus Zn; T6, minus lime; and T7, control with no lime or fertilizer.

\section{Root and forest floor litter sampling}

Forest floor litter was sampled in July 2012 using a square wooden template (100 $\mathrm{cm}^{2}$ ). Litter layers were classified according to Babel (1972) as: new litter (NL); old litter (OL); and fragmented layer (FL). The NL fraction was characterized by recently fallen needles with little or no color change. The $\mathrm{OL}$ fraction was characterized by needles with color change. The FL fraction was characterized by fractured litter and was passed through a $2 \mathrm{~mm}$ sieve to separate into coarse fragmented layer $(\mathrm{CFL})$ and fine fragmented layer (FFL). Dry mass and nutrient concentrations of fractions were determined. All roots were manually removed from the FFL for dry mass and nutrient concentration. In addition, roots samples were manually separated into thick and fine roots $(<1 \mathrm{~mm}$ diameter); fine roots were scanned for length and volume using WinRhizo ${ }^{\mathrm{TM}}$ (Regent Instrument Inc., Sainte-Foy, Quebec, Canada).

\section{Litter and fine root nutrient measurements}

After fraction separation, samples were oven dried at $60{ }^{\circ} \mathrm{C}$ until constant weight. For nutrient measurements, the dry digestion methodology of Martins \& Reissmann (2007) was used $\left(500{ }^{\circ} \mathrm{C}\right.$ with $\left.\mathrm{HCl} 3 \mathrm{~mol} \mathrm{~L}^{-1}\right)$. Concentrations of $\mathrm{Ca}, \mathrm{Mg}, \mathrm{Mn}, \mathrm{Fe}$, and $\mathrm{Al}$ were determined by atomic absorption spectrophotometry. Concentrations of $\mathrm{K}$ and $\mathrm{Na}$ were determined by flame spectrophotometry, and $\mathrm{P}$ concentration by the colorimetric method.

\section{Tree growth}

Tree growth was monitored by measuring diameter at breast height (DBH) and height of 16 trees in each plot. Measurements were performed in 2008 (start) and 2015 (end).

\section{Statistical analysis}

Data were subjected to Shapiro-Wilk and 
Bartlett tests to verify the assumptions of residual normality and variance homogeneity, respectively. Variables that did not present these characteristics were submitted to Box-Cox transformation. The Student-Newman-Keuls (SNK) test was used at the $5 \%$ probability level to check for possible differences between treatments. For tree growth data, the $10 \%$ probability level was used in the SNK test. After ensuring normality and homogeneity of data, a Principal Component Analysis (PCA) based on a correlation matrix was performed on litter layer elemental compositions and $\mathrm{C}: \mathrm{N}$ ratio. Statistical analyses were performed using the R software.

\section{Results and discussion}

\section{Forest floor litter fractions}

Almost four years after treatment applications, significant differences were observed in new litter layer concentrations of $\mathrm{Ca}, \mathrm{Mg}$, and $\mathrm{Na}$ (Tab. S1 in Supplementary material); $\mathrm{Ca}$ and $\mathrm{Mg}$ increased while $\mathrm{Na}$ decreased in treatments with lime. Additionally, results indicated high concentrations of $\mathrm{Al}$ and $\mathrm{Mn}$, which could be attributed to high soil acidity.

The highest $\mathrm{K}$ concentration for NL and $\mathrm{OL}$ was obtained by omission of lime ( $\mathrm{Ca}$ and $\mathrm{Mg}$ source), suggesting that $\mathrm{Ca}$ and $\mathrm{Mg}$ led to reduced $\mathrm{K}$ absorption. The antagonistic effect of $\mathrm{Ca}$ and $\mathrm{Mg}$ on $\mathrm{K}$ is well known (Epstein \& Bloom 2005). Omission of $K$ ( $-K$ treatment) lowered $K$ concentration only in the fine fragmented layer. However, omission along with other macronutrients (-macro) did not result in decreased $\mathrm{K}$. Thus, lime and micronutrient applications enhanced $\mathrm{K}$ uptake and maintenance for fall needs. The low concentration in treatments not receiving $\mathrm{K}$ was expected due to the low level in soil.

In general, $\mathrm{K}$ concentration was very low for both NL and OL. Rabel et al. (2020) reported higher levels in old and new litter for a $P$. taeda experiment in a nearby state. In addition, it is well known that large portions of $\mathrm{K}$ can be redistributed at rates greater than 90\% to growing parts of plants via translocation (Vieira \& Schumacher 2009), especially under $K$ deficiency. In this context, Rabel et al. (2020) reported that the second needle flush had ten times more $\mathrm{K}$ than the new litter layer. This high rate of redistribution could be a possible explanation for the lack of response.

Potassium concentration in forest floor fractions diminished as a result of tissue age. Diminishing $\mathrm{K}$ was expected since it is weakly bound to organic matter and can be easily leached from residues (Piatek \& Allen 2001). The observed decrease was not high, and it appears that the remaining $\mathrm{K}$ in dead needles stayed in tissue compartments susceptible to leaching. Precipitation passing through the canopy may have helped maintained $\mathrm{K}$ concentration.

In all forest floor layers analyzed, the ma- jor difference in composition was $\mathrm{Ca}$ and Mg concentrations (Tab. S1 in Supplementary material). These results were expected since $\mathrm{Ca}$ and $\mathrm{Mg}$ were added in larger amounts compared to $\mathrm{P}$ and $\mathrm{K}$, and soil at the experimental site had low levels of these bases. The interaction of bases was observed in NL since the minus $\mathrm{K}$ treatment had the highest concentration of $\mathrm{Mg}$ and a trend for $\mathrm{Ca}$.

Lime application overcame $\mathrm{Ca}$ and $\mathrm{Mg}$ loss due to forest floor aging in the control and enhanced concentration (more than 10 fold) in fragmented layers (Tab. S1). This accumulation in fragmented layers could be a result of adsorption by organic compounds and physical trapping of coarse lime particles. The presence of lime particles in coarse and fine fragmented layers was observed during sampling and laboratory processing. Large $\mathrm{Ca}$ and $\mathrm{Mg}$ increases in forest floor litter have been reported when lime has been applied (Matzner et al. 1985, Marschner \& Wilczynski 1991, Ingerslev 1997, Rosberg et al. 2006).

Although P concentration in NL was low, omission of this nutrient did not lead to further decreases, which was similar to findings for K (Tab. S1 in Supplementary material). As discussed for $K$, this could be related to high $\mathrm{P}$ redistribution from old to new tissue. In general, P concentration increased with litter age, possibly from $P$ binding to organic compounds during the litter decay process (Piatek \& Allen 2001). The minus lime and control treatments had lower $\mathrm{P}$ concentration in the $\mathrm{CFL}$, but $\mathrm{P}$ concentration for these two treatments did not increase from OL to CFL as seen in the other five treatments. This could be related to a delay in litter decay. Under acidic conditions, Martins (2011) reported an increase in $\mathrm{P}$ availability when lime application increased soil pH. The same author observed that a lack of response to fertilizer application can be associated with high translocation and the dilution effect.

Concentrations of $\mathrm{Al}$ and $\mathrm{Fe}$ were increased about three times in OL versus NL, with higher values being noted in FL (Tab. S1). These observations could be explained by a combination of three factors. First, the loss of $\mathrm{CO}_{2}$ during residue decay decreases mass and concentrates nutrients present in the residue. Second, elements that are strongly bond to organic matter undergo little impact from leaching; both $\mathrm{Al}$ and $\mathrm{Fe}$ are known to have strong adsorption capacity to organic matter (Kendorff \& Schnitzer 1980). Third, decomposition of Pinus residue can result in large amounts of organic acids under very acidic conditions, which are then able to attack and solubilize some contacted soil minerals. Since Al and Fe are major components of mineral soils and are strongly bound to organic acids, they remain in solution in large amounts. After solubilization, acid solutions rich in $\mathrm{Al}$

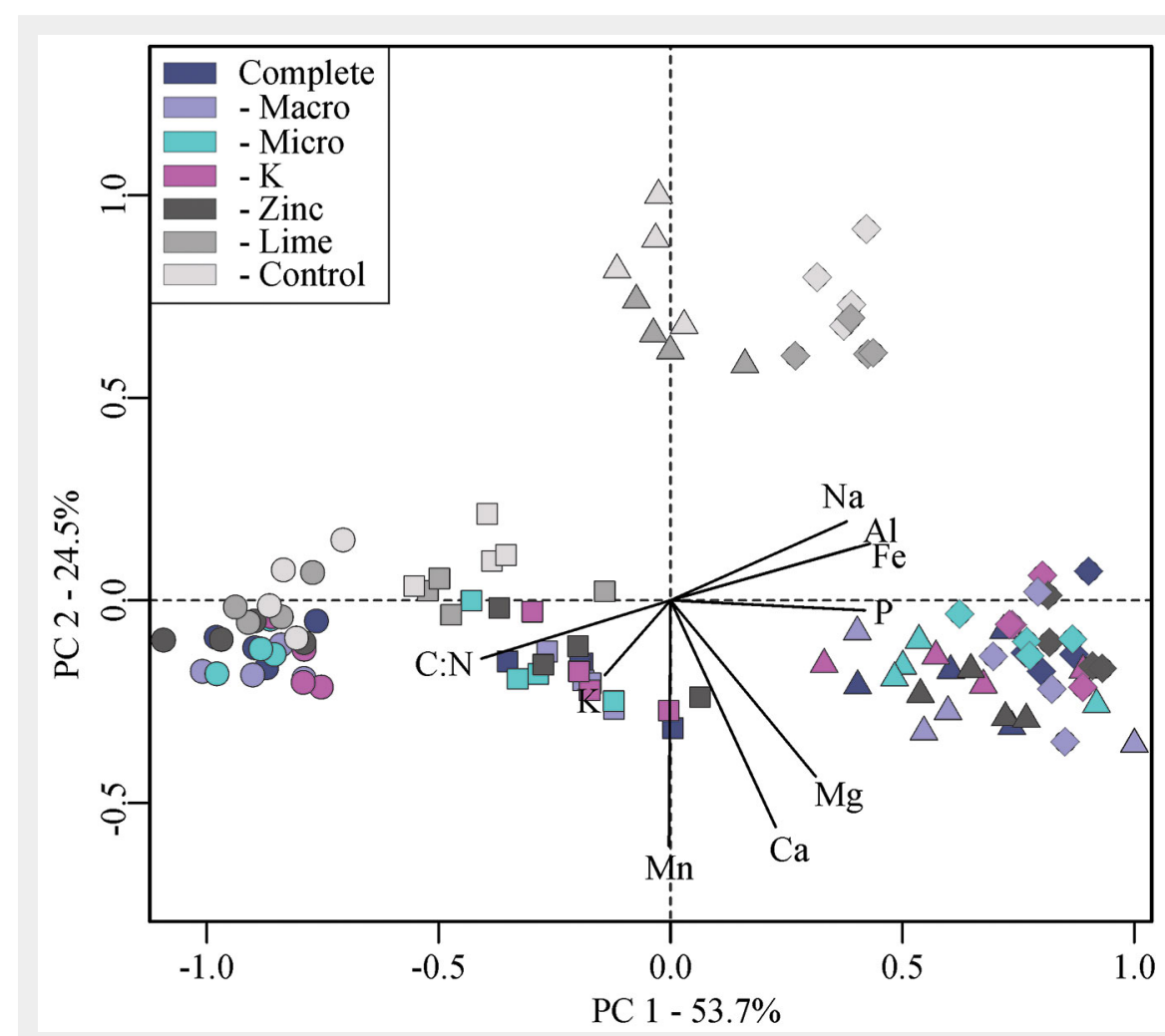

Fig. 1 - Principal component analysis of litter layer elemental compositions and C:N ratio for a Pinus taeda L. stand subjected to fertilizer and lime treatments in Paraná state, southern Brazil. Litter layers are represented by: new litter (circles); old litter (squares); coarse fragmented layer (triangles); fine fragmented layer (diamonds). 
Tab. 2 - Element concentration (nutrients, Al, and $\mathrm{Na}$ ) in fine roots from a Pinus taeda L. stand subjected to fertilizer and lime treatments in Paraná state, southern Brazil. Averages followed by the same letter in a column do not statistically differ ( $p>0.05)$ after Student-Newman-Keuls test. (CV): coefficient of variation.

\begin{tabular}{|c|c|c|c|c|c|c|c|c|}
\hline Treatment & $\begin{array}{c}\mathrm{Ca} \\
\left(\mathrm{g} \mathrm{kg}^{-1}\right)\end{array}$ & $\begin{array}{c}\mathrm{Mg} \\
\left(\mathrm{g} \mathrm{kg}^{-1}\right)\end{array}$ & $\begin{array}{c}P \\
\left(\mathrm{~g} \mathrm{~kg}^{-1}\right)\end{array}$ & $\begin{array}{c}\mathrm{K} \\
\left(\mathrm{mg} \mathrm{kg}^{-1}\right)\end{array}$ & $\underset{\left(\mathrm{mg} \mathrm{kg}^{-1}\right)}{\mathrm{Mn}}$ & $\begin{array}{c}\mathrm{Fe} \\
\left(\mathrm{mg} \mathrm{kg}^{-1}\right)\end{array}$ & $\begin{array}{c}\mathrm{Na} \\
\left(\mathrm{mg} \mathrm{kg}^{-1}\right)\end{array}$ & $\begin{array}{c}\mathrm{Al} \\
\left(\mathrm{g} \mathrm{kg}^{-1}\right)\end{array}$ \\
\hline Complete & $8.3^{a}$ & $2.7^{a}$ & $1.12^{\mathrm{ns}}$ & $329.5^{\mathrm{ns}}$ & $92.3^{a b c}$ & $620^{\mathrm{ns}}$ & $106.9^{a b}$ & $2.4^{\mathrm{ns}}$ \\
\hline - Macro & $7.0^{\mathrm{a}}$ & $2.6^{a}$ & 0.97 & 443.3 & $129.0^{\mathrm{ab}}$ & 432 & $112.1^{\mathrm{ab}}$ & 1.7 \\
\hline - Micro & $6.7^{\mathrm{a}}$ & $2.4^{a}$ & 1.03 & 398.8 & $172.4^{\mathrm{a}}$ & 521 & $69.2^{c}$ & 1.8 \\
\hline$-K$ & $7.2^{\mathrm{a}}$ & $2.5^{a}$ & 1.04 & 355.8 & $83.4^{\mathrm{abc}}$ & 595 & $135.4^{a}$ & 1.5 \\
\hline$-Z n$ & $7.6^{a}$ & $2.5^{\mathrm{a}}$ & 1.01 & 365.1 & $35.7^{\mathrm{bc}}$ & 597 & $88.6^{b}$ & 1.5 \\
\hline - Lime & $0.6^{\mathrm{b}}$ & $0.1^{\mathrm{b}}$ & 1.03 & 387 & $18.4^{c}$ & 551 & $138.9^{\mathrm{a}}$ & 1.8 \\
\hline Control & $0.2^{\mathrm{b}}$ & $0.1^{\mathrm{b}}$ & 0.85 & 298.6 & $115.1^{a b c}$ & 529 & $139.7^{\mathrm{ab}}$ & 2.1 \\
\hline$p$-value & $<0.01$ & $<0.01$ & 0.05 & 0.08 & $<0.01$ & 0.58 & $<0.01$ & 0.31 \\
\hline $\mathrm{CV}$ & 25.9 & 9.7 & 10.4 & 17.1 & 51.5 & 25.9 & 0.66 & 33 \\
\hline
\end{tabular}

and Fe can move upwards by capillarity action under dry conditions, thereby enhancing their concentrations in upper layers. The third explanation seems more plausible and was used by Trevisan (1992) to explain high concentrations of these elements. Litter contamination by Al due to soil bioturbation was likely since there was an increase in total Al with litter age, but the proportion of Al weakly and strongly bound to organic matter was different (Rodrigues et al. 2018). On the other hand, Rabel et al. (2020) recently showed that these more aged fractions usually have mixed soil, which can overestimate the concentration of Fe and Al.

The C: $\mathrm{N}$ ratio decreased to less than half its value when comparing the least decomposed layer $(\mathrm{NL})$ with the most decomposed layer (FFL - Tab. S1). Principal component analysis (PCA) indicated that PC1 explained $53.7 \%$ of data variance, and clearly showed the effect of litter aging (Fig. 1, Tab. S2 in Supplementary material). The less decomposed litter layers (NL and

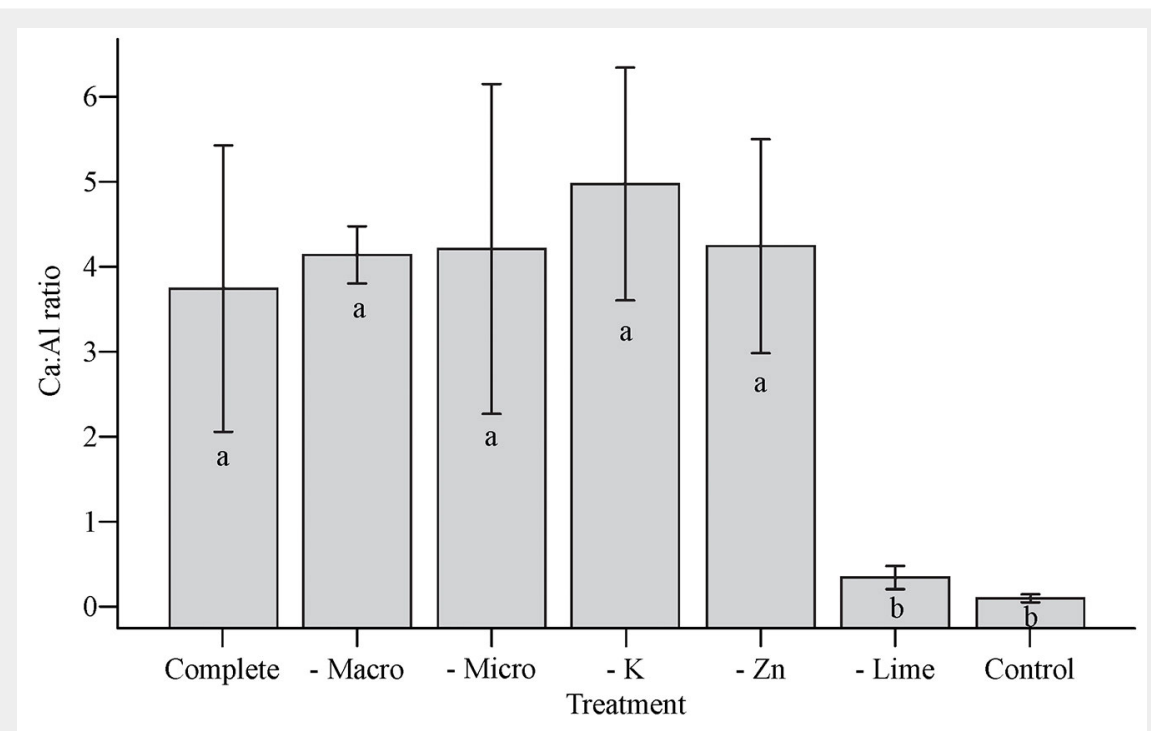

Fig. 2 - Molar ratio of Ca:Al concentrations in fine roots from a Pinus taeda L. (average \pm standard deviation) stand subjected to fertilizer and lime treatments in Paraná state, southern Brazil. Mg.
$\mathrm{OL})$ were associated with a higher $\mathrm{C}: \mathrm{N}$ ratio, while the opposite was true for the more decomposed layers. PCA also reinforced the strong effect of lime as evidenced by the position of the minus lime and control treatments, which were separated from other treatments for the same litter layer. These were also associated with lower concentrations of $\mathrm{Mn}, \mathrm{Ca}$, and

Acidity appeared to have a strong influence on Mn. For NL, the Mn concentration exhibited a trend to be higher for the control and minus lime treatments than limed treatments, which was expected since acidity increases soil $\mathrm{Mn}$ availability (Prado 2008). In contrast, the high acidic conditions found in the minus lime and control treatments resulted in a great loss of $\mathrm{Mn}$, which was reflected by a sharp decline from OL to CFL, followed by maintenance of concentration in FFL. The higher Mn loss when lime was not applied can be associated with low CEC and retention to forest floor organic material (Kendorff \& Schnit-

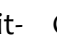

Liming did not reduce root Al concentration despite the high enhancement of $\mathrm{Ca}$ and $\mathrm{Mg}$. It is well known that $\mathrm{Al}$ is an important factor limiting pine tree development under extreme acidic conditions, and that Ca can mitigate Al toxicity, suggesting that the Ca:Al molar ratio can be used to diagnose Al toxicity (Vangelova et al. 2007). Thus, lime application that enhanced $\mathrm{Ca}$ concentration without changing $\mathrm{Al}$ concentration (as seen in our study - Fig. 2) indicated a diminishment of Al toxicity (Bakker 1999).

The Ca:Al molar ratio critical threshold has been studied by many authors; $40 \%$ reported the critical threshold to be between $0.3-0.7,50 \%$ reported a value between 0.2 0.3 , and $10 \%$ reported values below 0.2 (Vangelova et al. 2007). The Ca:Al molar ratio for the treatments without lime and control showed that our studied pine stand was under Al toxicity.

There were slight changes in concentration of $\mathrm{Na}, \mathrm{K}$, and $\mathrm{P}$ that ranged from 69.2 to $139.7 \mathrm{mg} \mathrm{kg}^{-1}, 298.6$ to $443.3 \mathrm{mg} \mathrm{kg}^{-1}$, and 
0.9 to $1.1 \mathrm{~g} \mathrm{~kg}^{-1}$, respectively. The lowest values for $K$ and $P$ were observed in the control treatment.

Higher amounts of Fe were found in roots (Tab. 2) than in the NL layer (Tab. S1 in Supplementary material); this suggests that upward translocation ability was greater for $\mathrm{Mn}$ than Fe. Roots had low values of Mn (Tab. 2), but high values in NL suggests more translocation of this nutrient to the aboveground biomass. The lowest Mn concentration was observed with omission of lime, which was in agreement with total concentration values observed in FL (Tab. S1). However, the concentration in the control was much higher than the minus lime treatment despite the low total concentration found in FL. More study is required to evaluate the effects of lime on root $\mathrm{Mn}$ concentrations.

\section{Forest floor litter accumulation}

The total amount of forest floor litter accumulation varied from 43.9 to $52.1 \mathrm{t} \mathrm{ha}^{-1}$ (Tab. 3), which was within the large range of 20.3 to $90.6 \mathrm{t} \mathrm{ha}^{-1}$ reported by Bizon (2005) in a Pinus survey for this region. The amount of litter found in our study can be considered high and was indicative of a poor growth site with low soil fertility (Motta et al. 2014, Vogel et al. 2015).

Poor growth sites are generally charac terized by low soil fertility that leads to low soil microbiological activity. Plants grown under soil nutrient deficiency generally have low tissue nutrient concentrations that may restrict decomposition rates.

There was no difference in forest floor litter accumulation among treatments. Similar results for fertilization were reported by Moro (2017) who evaluated stands of $P$. taeda that were one, five, and nine years old. Prescott (1995) also observed that mass loss of pine forest floor litter was similar in control plots and plots fertilized with $\mathrm{N}$ or NPK.

The small variation in the amount of new litter layer mass ranging from 3.74 to $4.38 \mathrm{t}$ ha $^{-1}$ (Tab. 3) suggests similar needle fall regardless of treatment application. The combined amount of NL and OL represents only $17.1 \%$ to $23.6 \%$ of total forest floor lit-

Tab. 3 - Forest floor litter layer accumulation ( $t \mathrm{ha}^{-1}$ ) from a Pinus taeda L. stand subjected to fertilizer and lime treatments in Paraná state, southern Brazil. (CV) coefficient of variation. Averages followed by the same letter do not statistically differ ( $p>0.05)$ after Student-Newman-Keuls test.

\begin{tabular}{lccccc}
\hline \multirow{2}{*}{ Treatments } & \multicolumn{5}{c}{ Forest floor litter layers } \\
\cline { 2 - 6 } & $\begin{array}{c}\mathrm{NL} \\
(\mathrm{t} \mathrm{ha}\end{array}$ & $\begin{array}{c}\text { OL } \\
\left(\mathrm{t} \mathrm{ha}^{-1}\right)\end{array}$ & $\begin{array}{c}\mathrm{CFL} \\
\left(\mathrm{t} \mathrm{ha}^{-1}\right)\end{array}$ & $\begin{array}{c}\mathrm{FFL} \\
\left(\mathrm{t} \mathrm{ha}^{-1}\right)\end{array}$ & Total \\
\hline Complete & 4.32 & 5.37 & 26.28 & 16.15 & 52.12 \\
\hline - Macro & 3.89 & 5.98 & 25.24 & 15.51 & 50.62 \\
\hline - Micro & 4.13 & 6.03 & 22.88 & 15.81 & 48.85 \\
\hline - K & 3.74 & 5.95 & 21.32 & 14.75 & 45.76 \\
\hline - Zn & 4.33 & 6.04 & 21.48 & 12.10 & 43.95 \\
\hline - Lime & 4.27 & 5.11 & 23.08 & 16.97 & 49.43 \\
\hline Control & 4.38 & 5.28 & 23.80 & 16.19 & 49.65 \\
\hline Average & $4.15^{\mathrm{c}}$ & $5.68^{\mathrm{c}}$ & $23.44^{\mathrm{a}}$ & $15.35^{\mathrm{b}}$ & - \\
\hline p-value Treatments & 0.62 & - & - & - & - \\
\hline p-value Layers & $<0.01$ & - & - & - & - \\
\hline p-value T $\times$ L & 0.98 & - & - & - & - \\
\hline CV Treatments (\%) & 39 & - & - & - & - \\
\hline CV Layers (\%) & 34.4 & - & - & - & - \\
\hline
\end{tabular}

ter. This amount was close to the annual litter depositions (6.4 and $9.3 \mathrm{t} \mathrm{ha}^{-1}$ ) observed by Bizon (2005) under similar soil and climatic conditions and by Piovesan et al. (2012) who found $7.1 \mathrm{t} \mathrm{ha-1}^{-1}$ in an 8-year-old pine plantation. Schumacher et al. (2008) also reported that $P$. taeda ( 5 to 7 years old) had a deposition of $4.52 \mathrm{t} \mathrm{ha}^{-1}$ year-1. Our finding suggests that these litter layers were composed of recently fallen needles (one year old).

The CFL and FFL litter layers comprised $50 \%$ and $30 \%$ of total forest floor litter mass, respectively. Age of the fragmented residue was not established, but some portion of the litter layer may have been contributed by the first pine rotation since fire was not used to clear the area after the first rotation harvest. Forest floor litter composed of fine material could be more stable and a major reservoir of nutrients, as well as a source of energy for microorganisms.

In the case of fine roots (Fig. $3 \mathrm{~A}$ ), there was no significant effect, although in- creased biomass was observed in the complete treatment compared to the no lime treatment; this supports the Ca:Al ratio results. This shows that roots developed more when nutrient availability increased. Lehto (1994) in Scotland observed that there was an increase in fine root biomass in Picea abies with liming (after 30 years) and boron (after 2 years). Under temperate conditions, Bakker et al. (2009) found a decrease in fine root biomass of Pinus pinaster with the addition of nutrients ( $\mathrm{N}, \mathrm{P}, \mathrm{K}$, $\mathrm{Ca}$, and $\mathrm{Mg}$ ) in both the forest floor and soil compartments. Working with P. taeda, Albaugh et al. (1998) found increases in total aboveground biomass and coarse roots with fertilization, but no change in fine root biomass, which indicated a greater allocation of metabolic resources to foliage (photosynthesizing tissue) over fine roots. Samuelson et al. (2004) observed no change in $P$. taeda fine root biomass as a result of fertilization.

In general, fine root biomass obtained in this study was higher than seen in other
Fig. 3 - Dry mass (A), length $(B)$, and volume (C) of fine roots (average \pm standard deviation) present in forest floor litter from a Pinus taeda L. stand subjected to fertilizer and lime treatments in Paraná state, southern Brazil. (ns): not significant.
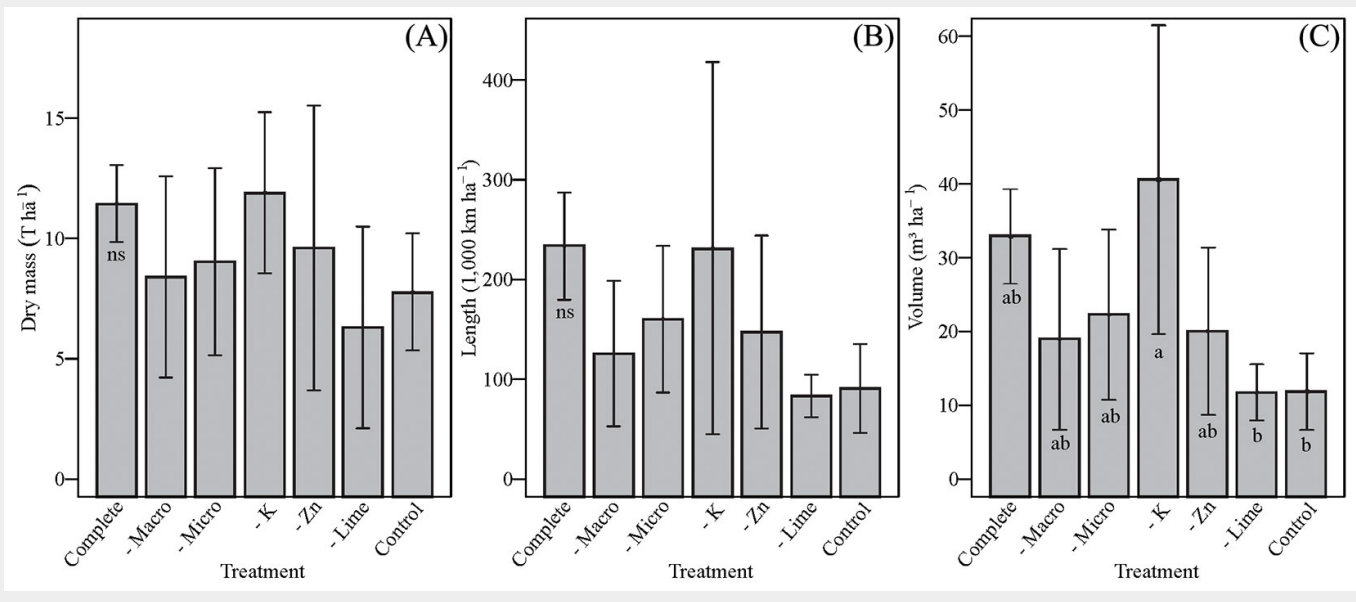
Tab. 4 - Total nutrients (C, N, Ca, Mg, P, K, Mn, and Fe), Al, and $\mathrm{Na}$ in forest floor litter from a Pinus taeda L. stand subjected to fertilizer and lime treatments in Paraná state, southern Brazil. Averages followed by the same letter in a column do not statistically differ ( $p>0.05)$ after Student-Newman-Keuls test. (CV): coefficient of variation.

\begin{tabular}{|c|c|c|c|c|c|c|c|c|c|c|}
\hline Treatment & $\begin{array}{c}\mathrm{C} \\
\left(\mathrm{kg} \mathrm{ha}^{-1}\right)\end{array}$ & $\begin{array}{c}\mathrm{N} \\
\left(\mathrm{kg} \mathrm{ha}^{-1}\right)\end{array}$ & $\begin{array}{c}\mathrm{Ca} \\
\left(\mathrm{kg} \mathrm{ha}^{-1}\right)\end{array}$ & $\begin{array}{c}M g \\
\left(k^{M g a^{-1}}\right)\end{array}$ & $\begin{array}{c}P \\
\left(k^{\prime} a^{-1}\right)\end{array}$ & $\begin{array}{c}\mathrm{K} \\
\left(\mathrm{kg} \mathrm{ha}^{-1}\right)\end{array}$ & $\begin{array}{c}\mathrm{Mn} \\
\left(\mathrm{kg} \mathrm{ha}^{-1}\right)\end{array}$ & $\begin{array}{c}\text { Fe } \\
\left(\mathrm{kg} \mathrm{ha}^{-1}\right)\end{array}$ & $\begin{array}{c}\text { Al } \\
\left(\mathrm{kg} \mathrm{ha}^{-1}\right)\end{array}$ & $\begin{array}{c}\mathrm{Na} \\
\left(\mathrm{kg} \mathrm{ha}^{-1}\right)\end{array}$ \\
\hline Complete & 23,130 & 577 & $475^{a}$ & $135^{a}$ & 47.7 & 12.7 & $19.9^{a}$ & 44.5 & 268 & 4.38 \\
\hline - Macro & 21,023 & 525 & $562^{a}$ & $135^{a}$ & 43.5 & 13.3 & $21.8^{a}$ & 36.2 & 222 & 5.22 \\
\hline - Micro & 25,108 & 640 & $545^{a}$ & $144^{\mathrm{a}}$ & 58.5 & 14.2 & $19.2^{\mathrm{a}}$ & 44.9 & 235 & 4.47 \\
\hline$-\mathrm{K}$ & 20,401 & 515 & $376^{a}$ & $107^{a}$ & 45.6 & 10.3 & $18.1^{\mathrm{ab}}$ & 31.0 & 200 & 4.17 \\
\hline$-\mathrm{Zn}$ & 18,911 & 486 & $440^{a}$ & $107^{a}$ & 43.9 & 11.6 & $18.1^{\mathrm{ab}}$ & 35.0 & 180 & 3.46 \\
\hline - Lime & 23,162 & 578 & $46^{b}$ & $11^{\mathrm{b}}$ & 38.8 & 13.0 & $5.4^{\mathrm{bc}}$ & 35.5 & 215 & 4.41 \\
\hline Control & 22,266 & 584 & $31^{\mathrm{b}}$ & $10^{b}$ & 31.8 & 10.3 & $4.8^{c}$ & 36.7 & 205 & 4.20 \\
\hline$p$-value & 0.47 & 0.33 & $<0.01$ & $<0.01$ & 0.06 & 0.28 & $<0.01$ & 0.36 & 0.66 & 0.36 \\
\hline $\mathrm{CV}$ & 18.9 & 16.9 & 34.3 & 22.3 & 23.4 & 21.2 & 37.7 & 25.2 & 31.2 & 22.2 \\
\hline
\end{tabular}

studies (3.5 $\mathrm{t} \mathrm{ha}^{-1}$ maximum) that considered forest floor litter and/or soil (Albaugh et al. 1998, Samuelson et al. 2004, Lopes et al. 2010). Under limiting conditions, fine roots in pine forest floor litter play important roles in recycling nutrients and providing nutrients and water to trees (Lopes et al. 2010, Motta et al. 2014).

Omission of $\mathrm{K}$ alone (minus $\mathrm{K}$ ) resulted in higher fine root volume, indicating that it may be a limiting element and that its absence stimulates plants to produce more roots for enhanced absorption of this nutrient. Yavitt et al. (2011) showed root decreases with $\mathrm{K}$ application in a tropical forest in Panama during a 4 year evaluation. Following the same logic, Sayer et al. (2012) studied nutrient cycling in a tropical forest and found that fine root activity was lower in sites with added $\mathrm{K}$.

Nutrients and $\mathrm{Al}$ in forest floor litter Total amounts of immobilized elements in forest floor litter are shown in Tab. 4, while values for individual litter layers are given in Tab. S3 (Supplementary material). Results from the control treatment followed the sequence $\mathrm{C}>\mathrm{N}>\mathrm{Al}>\mathrm{Fe}>\mathrm{P}>\mathrm{Ca}>\mathrm{K}>\mathrm{Mg}>$ $\mathrm{Mn}>\mathrm{Na}$, while the complete treatment followed the sequence $\mathrm{C}>\mathrm{N}>\mathrm{Ca}>\mathrm{Al}>\mathrm{Mg}>\mathrm{P}>$ $\mathrm{Fe}>\mathrm{Mn}>\mathrm{K}>\mathrm{Na}$. Matzner et al. (1985) reported similar results for spruce forest floor litter with the order $\mathrm{C}>\mathrm{N}>\mathrm{Fe}>\mathrm{Al}>\mathrm{Ca}>$ $\mathrm{P}>\mathrm{K}>\mathrm{Mg}>\mathrm{Mn}$ for the control and $\mathrm{C}>\mathrm{N}>$ $\mathrm{Ca}>\mathrm{Fe}>\mathrm{Mg}>\mathrm{Al}>\mathrm{P}>\mathrm{Mn}>\mathrm{K}$ for fertilizer treatments. Given the observed total forest floor biomass values, $\mathrm{C}$ and $\mathrm{N}$ maintenance in forest floor litter were not affected by lime and fertilizer applications in contrast to findings of Huber et al. (2006).

Again, the main observed differences were related to $\mathrm{Ca}$ and $\mathrm{Mg}$, with no differences for other macronutrients $(\mathrm{N}, \mathrm{P}, \mathrm{K})$. Rosberg et al. (2006) and Marschner \& Wilczynski (1991) reported large increases in Ca (213-1476 kg ha-1 and 140-1540 kg ha-1,

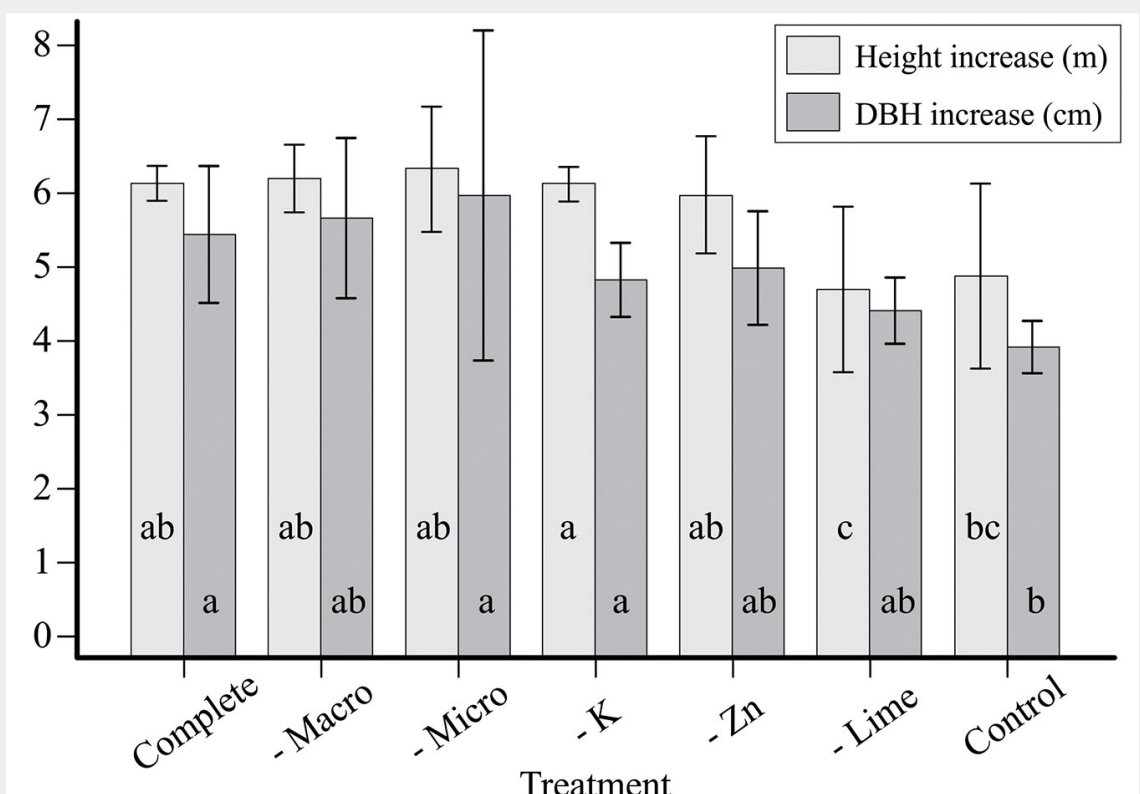

Fig. 4 - Diameter at breast height (DBH) and height increases (average \pm standard deviation) from 2008 to 2015 for each treatment. respectively) and $\mathrm{Mg}$ (34-690 $\mathrm{kg} \mathrm{ha}^{-1}$ and 40-107 $\mathrm{kg} \mathrm{ha}^{-1}$, respectively) from liming and fertilization, but low increases in $\mathrm{N}$ (1092-1159 kg ha-1 and $1060-930 \mathrm{~kg} \mathrm{ha}^{-1}$, respectively), $\mathrm{P}$ (62-74 kg ha-1 and 89-102 kg $\mathrm{ha}^{-1}$, respectively) and $\mathrm{K}$ ( $57-72 \mathrm{~kg} \mathrm{ha}^{-1}$ and 34-41 $\mathrm{kg} \mathrm{ha}^{-1}$, respectively).

As previously discussed, a portion of applied lime was trapped in CFL and FFL and could be visually observed during sample manipulation. Huber et al. (2006) reported the complete dissolution of $4 \mathrm{t} \mathrm{ha}^{-1}$ of dolomitic lime 6 years after application, which confirms the slow solubility of lime applied over forest floor litter. Some lime was probably solubilized and $\mathrm{Ca}$ and $\mathrm{Mg}$ were adsorbed to negative charges associated with forest floor litter (Ingerslev 1997). This supports observations of Rosberg et al. (2006) who found that $~ 90 \%$ of Ca applied as lime was found in forest floor litter four years after application.

The observed increase in Ca was proportionally higher than $\mathrm{Mg}$ since the $\mathrm{Ca}: \mathrm{Mg}$ ratio of the utilized lime was 1.7:1, while the forest floor litter had a 3:1 ratio. Since there is an inverse relationship between adsorption strength and loss by leaching, the higher adsorption capacity of Ca compared to $\mathrm{Mg}$ resulted in the maintenance of $\mathrm{Ca}$ in forest floor litter. In a long-term study, Huber et al. (2006) also found much higher leaching of $\mathrm{Mg}$ than $\mathrm{Ca}$.

Treatments with lime increased $\mathrm{Mn}$ in litter, similar to observations by Marschner \& Wilczynski (1991) and Matzner et al. (1985). Huber et al. (2006) found a decrease of $M n$ due to lime application in seepage water at a $40 \mathrm{~cm}$ depth, confirming its maintenance in forest floor litter and soil.

Matzner et al. (1985) also reported increased Fe and Al, while Marschner \& Wilczynski (1991) did not report differences. Matzner et al. (1985) suggested that soil bioturbation could be a reason for increases in $\mathrm{Al}, \mathrm{Fe}$, and $\mathrm{Mn}$; this was not observed in our study. Thus, the low amount of $\mathrm{Mn}$ under acidic conditions could be related to the adsorption capacity of organic matter.

Observed results also indicated that for- 
est floor litter can be a major source of $P$ when fertilizer and lime were not applied. This was likely true in our study since $P$ was found in high amounts in forest floor litter and was less exported and extracted by pine trees (Martins 2011).

In contrast, forest floor litter displayed little potential as a $\mathrm{K}$ source since low amounts were available to meet the large demands of $P$. taeda. This was expected due to the redistribution capacity from old growth to new growth. Thus, $K$ was redistributed from needles prior to senescence and litterfall (Vieira \& Schumacher 2009).

\section{Tree growth}

Small increases in DBH and tree height (similar to control) as a result of lime omission (Fig. 4) suggest a probable lack of $\mathrm{Mg}$ and/or Ca. Since $\mathrm{Mg}$ availability was lower than $\mathrm{Ca}$ and was very low within the 0-60 $\mathrm{cm}$ depth (Tab. 1), it is plausible that $\mathrm{Mg}$ was more limiting when lime was omitted. Omission of lime also resulted in the appearance of chlorotic symptoms in needles tips (yellowish color), especially in the first needle flush. These symptoms resembled the lack of $\mathrm{Mg}$ reported for Pinus radiata (D. Don) plantations in New Zealand that displayed distal yellowing of older needles (Will 1978).

At our study site, omission of $\mathrm{K}$ produced the highest tree growth despite extremely low soil $\mathrm{K}$ levels. Potassium levels in plants may be highly associated with non-exchangeable $\mathrm{K}$ in soil, indicating an ability of $P$. taeda to acquire soluble forms (Alves et al. 2013). In addition, the well known antagonistic interaction between $\mathrm{K}$ and $\mathrm{Mg}$ (Sun \& Payn 1999, Consalter et al. 2020) can decrease $\mathrm{Mg}$ uptake when $\mathrm{K}$ is applied.

\section{Conclusions}

There were high increases in $\mathrm{Ca}$ and $\mathrm{Mg}$ concentrations in forest floor litter due to the high amounts of lime applied. Better growth was observed with lime application since lime is a good source of $\mathrm{Ca}$ and $\mathrm{Mg}$ that provides more optimal conditions for fine root growth and can lead to decreased Al toxicity. Also, symptoms of $\mathrm{Mg}$ deficiency with lime omission illustrates the importance of dolomitic lime in Pinus taeda forests having very low levels of available soil Mg. In our poor soil system, K was not present in great quantities in litter and fine root fractions likely due to the efficient redistribution capacity of pine trees from old growth to new growth. Fertilizer addition caused little variation in the amount of accumulated forest floor litter, indicating a balance of inputs and outputs or that nutrition had little impact on forest floor litter decomposition. Forest floor litter acted as a nutrient pool and had the following order of availability under control conditions: $\mathrm{C}>\mathrm{N}>\mathrm{Fe}>\mathrm{P}>\mathrm{Ca}>\mathrm{K}>\mathrm{Mg}>\mathrm{Mn}$. Under amended conditions the sequence was: $\mathrm{C}>\mathrm{N}>\mathrm{Ca}>$ $\mathrm{Mg}>\mathrm{P}>\mathrm{Fe}>\mathrm{Mn}>\mathrm{K}$. Lime application increased the amount of $\mathrm{Ca}$ and $\mathrm{Mg}$ in litter but had no effect on $\mathrm{C}, \mathrm{N}, \mathrm{K}$, and $\mathrm{P}$.

\section{Acknowledgements}

The authors thank the staff (Renato Teixeira Lima, Antônio - Mineiro, Felipe Mazurki Perucio) of the "Vale do Corisco" and "Valor Florestal" Companies for field work support, and Barry Dorman of the USDAARS National Soil Dynamics Laboratory for technical review of the manuscript. ACVM is grateful to the National Council for Scientific and Technological Development of Brazil (CNPq) for financial support and to the "Coordination for the Improvement of Higher Education Personnel" (CAPES, Brazil) for scholarship support.

\section{References}

Albaugh TJ, Allen HL, Dougherty PM, Kress LW, King JS (1998). Leaf area and above-and belowground growth responses of loblolly pine to nutrient and water additions. Forest Science 44 (2): 317-328. [online] URL: http://academic.oup. com/forestscience/article/44/2/317/4627497

Alvares CA, Stape JL, Sentelhas PC, Gonçalves JLM, Sparovek G (2013). Köppen's climate classification map for Brazil. Meteorologische Zeitschrift 22 (6): 711-728. - doi: 10.1127/0941-2948/ 2013/0507

Alves MJF, Melo VF, Reissmann CB, Kaseker JF (2013). Reserva mineral de potássio em Latossolo cultivado com Pinus taeda L. [Mineral potassium reserve in an Oxisol cultivated with Pinus taeda L.]. Revista Brasileira de Ciência do Solo 37: 1599-1610. [in Portuguese] - doi: 10.1590/S0100-06832013000600016

Babel U (1972). Moderprofile in Wäldern - Morphologie und Umsetzungsprozesse [Moder profiles in forests - Morphology and implementation processes]. Hohenheimer Arbeiten 60, Ulmer, Stuttgart, Germany, pp. 120. [in German]

Bakker MR (1999). Fine roots parameters as sustainability of forest ecosystems. Forest Ecology and Management 122: 7-16. - doi: 10.1016/S03781127(99)00028-6

Bakker MR, Jolicoeur E, Trichet P, Augusto L, Plassar DC, Guinberteau J, Loustau D (2009). Adaptation of fine roots to annual fertilization and irrigation in a 13-year-old Pinus pinaster stand. Tree Physiology 29 (2): 229-238. - doi: 10.1093/treephys/tpnozo

Batista AH, Motta ACV, Reissmann CB, Schneider T, Martins IL, Hashimoto M (2015). Liming and fertilisation in Pinus taeda plantations with severe nutrient deficiency in savanna soils. Acta Scientiarum Agronomy 37 (1): 117-125. - doi: 10.4025/actasciagron.v37i1.18061

Bauhus J, Bartsch N, Cowling N (2004). The effects of gaps and liming on forest floor decomposition and soil $\mathrm{C}$ and $\mathrm{N}$ dynamics in a Fagus sylvatica forest. Canadian Journal of Forest Research 34 (3): 509-518. - doi: 10.1139/Х03-218

Berg B, Davey MP, Marco A, Emmett B, Faituri M, Hobbie SE, Rutigliano FA (2010). Factors influencing limit values for pine needle litter decomposition: a synthesis for boreal and temperate pine forest systems. Biogeochemistry 100 (1-3): 57-73. - doi: 10.1007/s10533-009-9404-y Bizon JMC (2005). Avaliação da sustentabilidade nutricional de plantios de Pinus taeda L. usando um balanço de entrada e saída de nutrientes [Assessment of the nutritional sustainability of
Pinus taeda L. plantations using a nutrient input and output balance]. Dissertação de mestrado, Escola Superior de Agricultura "Luiz de Queiroz", USP, Piracicaba, Brazil, pp. 96. [in Portuguese]

Carlson CA, Fox TR, Allen HL, Albaugh TJ, Rubilar RA, Stape JL (2013). Growth responses of loblolly pine in the southeast united states to midrotation applications of nitrogen, phosphorus, potassium, and micronutrients. Forest Science 60 (1): 157-169. - doi: 10.5849/forsci.12-158 Consalter R, Barbosa JZ, Prior SA, Vezzani FM, Bassaco MVM, Pedreira GQ, Motta ACV (2020). Mid-rotation fertilization and liming effects on nutrient dynamics of Pinus taeda L. in subtropical Brazil. European Journal of Forest Research 140 (1): 19-35. - doi: 10.1007/s10342-020-01305-4 Donagema GK, Campos DB, Calderano SB, Teixeira WG, Viana JM (2011). Manual de métodos de análise de solo [Manual of soil analysis methods]. Embrapa Solos-Documentos (INFOTECA-E), Rio de Janeiro, Brazil, pp. 230. [in Portuguese]

Epstein E, Bloom AJ (2005). Mineral nutrition of plants: principles and perspectives. Sinauer Associates, Sunderland, MS, USA, pp. 400.

Huber C, Baier R, Göttlein A, Weis W (2006). Changes in soil, seepage water and needle chemistry between 1984 and 2004 after liming an $\mathrm{N}$-saturated Norway spruce stand at the Höglwald, Germany. Forest Ecology and Management 233 (1): 11-20. - doi: 10.1016/j.foreco.20 06.05 .058

Huntington TG (2000). The potential for calcium depletion in forest ecosystems of southeastern United States: review and analysis. Global Biogeochemical Cycles 14 (2): 623-638. - doi: 10.1029/1999GB001193

Ingerslev M (1997). Effects of liming and fertilization on growth, soil chemistry and soil water chemistry in a Norway spruce plantation on a nutrient-poor soil in Denmark. Forest Ecology Management 92 (1-3): 55-66. - doi: 10.1016/So 378-1127(96)03964-3

Jandl R, Kopeszki H, Bruckner A, Hager H (2003). Forest soil chemistry and mesofauna 20 years after an amelioration fertilization. Restoration Ecology 11 (2): 239-246. - doi: 10.1046/j.1526-100 X.2003.00179.X

Kendorff H, Schnitzer M (1980). Sorption of metals on humic acid. Geochimica and Cosmochimica Acta 44: 1701-1708. - doi: 10.1016/0016-7037 (80)90221-5

Kiser IC, Fox TR, Carlson CA (2013). Foliage and Litter Chemistry, Decomposition, and Nutrient Release in Pinus taeda. Forests 4 (3): 595-612. doi: $10.3390 / 44030595$

Lehto T (1994). Effects of liming and boron fertilization on boron uptake of Picea abies. Plant and Soil 163 (1): 55-64. - doi: 10.1007/BFo003 3940

Lopes VG, Schumacher MV, Calil FN, Vieira M, Witschoreck R (2010). Fine roots quantification in Pinus taeda L. stand and grassland area in Cambará do Sul (RS). Ciência Florestal 20 (4): 569-578. - doi: 10.5902/198050982415 Marques R, Motta ACV (2003). Análise química do solo para fins de fertilidade [Chemical soil analysis for fertility purposes]. In: "Manual de Diagnóstico da Fertilidade e Manejo dos Solos Agrícolas" (De Lima MR ed). Departamento de 
Solos e Engenharia Agrícola, Curitiba, Brazil, pp. 81-102. [in Portuguese]

Marschner B, Wilczynski A (1991). The effect of liming on quantity and chemical composition of soil organic matter in a pine forest in Berlin, Germany. Plant and Soil 137 (2): 229-236. - doi: 10.1007/BFoo011201

Martins APL, Reissmann CB (2007). Material vegetal e as rotinas laboratoriais nos procedimentos químico-analíticos [Plant material and laboratory routines in chemical-analytical procedures]. Scientia Agraria 8 (1): 1-17. - doi: 10.5380/ rsa.v8i1.8336

Martins IL (2011). Análise nutricional do P em um povoamento de Pinus taeda L. submetido a um ensaio de omissão de nutrientes. [Nutritional analysis of $\mathrm{P}$ in a stand of Pinus taeda L. submitted to a nutrient omission test]. Dissertação de Mestrado, Departamento de Solos e Engenharia Agrícola, Setor de Ciências Agrárias, Universidade Federal do Paraná, Curitiba, PR, Brazil, pp. 96. [in Portuguese]

Matzner E, Khanna PK, Meiwes KJ, Ulrich B (1985). Effects of fertilization and liming on the chemical soil conditions and element distribution in forest soils. Plant and Soil 87 (3): 405415. - doi: 10.1007/BF02181907

Moro L (2017). Produtividade, ciclagem de nutrientes e índices do sistema dris em plantios de pinus submetidos à adubação NPK em três idades [Productivity, nutrient cycling and indexes of the dris system in pine plantations submitted to NPK fertilization at three ages]. Tese de Doutorado, Centro de Ciências Agroveterinárias, Universidade do Estado de Santa Catarina, Lages, SC, Brazil, pp. 93. [in Portuguese]

Motta ACV, Barbosa JZ, Consalter R, Reissmann CB (2014). Nutrição e Adubação da Cultura de Pínus [Pine Crop Nutrition and Fertilization]. In: "Nutrição e Adubação de Espécies Florestais e Palmeiras" (Prado, RM, Wadt PGS eds). Jaboticabal, FUNEP, São Paulo, Brazil, pp. 383-426. [in Portuguese]

Persson T, Rudebeck A, Wiren A (1995). Pools and fluxes of carbon and nitrogen in 40-yearold forest liming experiments in southern Sweden. Water, Air, and Soil Pollution 85 (2): 901906. - doi: 10.1007/BF00476944

Piatek KB, Allen HL (2001). Are forest floors in mid-rotation stands of loblolly pine (Pinus taeda) a sink for nitrogen and phosphorus? Canadian Journal of Forest Research 31 (7): 1164-1174. - doi: 10.1139/x01-049

Piovesan G, Schumacher MV, Viera M, Lopes VG, Welter C (2012). Deposição de serapilheira em povoamento de pinus [Litterfall deposition in a pine stand]. Pesquisa Agropecuária Tropical 42: 206-211. [in Portuguese] - doi: 10.1590/S1983-40 632012000200012

Prado RM (2008). Nutrição de plantas [Plant nutrition]. UNESP, São Paulo, Brazil, pp. 507. [in Portuguese]

Prescott CE, Corbin JP, Parkinson D (1992). Immobilization and availability of $N$ and $P$ in the forest floors of fertilized Rocky Mountain coniferous forests. Plant and Soil 143: 1-10. - doi: 10.1007/BFoooog123

Prescott CE (1995). Does nitrogen availability control rates of litter decomposition in forests?
Plant and Soil 168: 83-88. - doi: 10.1007/BFooo 29316

Prietzel J, Rehfuess KE, Stetter U, Pretzsch H (2008). Changes of soil chemistry, stand nutrition, and stand growth at two Scots pine (Pinus sylvestris L.) sites in Central Europe during 40 years after fertilization, liming, and lupine introduction. European Journal of Forest Research 127 (1): 43-61. - doi: 10.1007/s10342-007-0181-7

Rabel DO, Maeda S, Araujo EM, Gomes JB, Bognolla IA, Prior SA, Magri E, Frigo C, Brasileiro BP, Santos MC, Pedreira GQ, Motta ACV (2020). Recycled alkaline paper waste influenced growth and structure of Pinus taeda L. forest. New Forests 51: 1-22. - doi: 10.1007/s11056-02009791-5

Rizvi SH, Gauquelin T, Gers C, Guérold F, Pagnout C, Baldy V (2012). Calcium-magnesium liming of acidified forested catchments: effects on humus morphology and functioning. Applied Soil Ecology 62: 81-87. - doi: 10.1016/j.apsoil.2012.07. 014

Rodrigues ANA, Motta ACV, Goularte GD, Prior SA (2018). Forms and buffering potential of aluminum in tropical and subtropical acid soils cultivated with Pinus taeda L. Journal of Soils and Sediments 19 (3): 1355-1366. - doi: $10.1007 / \mathrm{s} 1136$ 8-018-2144-7

Rosberg I, Frank J, Stuanes AO (2006). Effects of liming and fertilization on tree growth and nutrient cycling in a Scots pine ecosystem in Norway. Forest Ecology and Management 237 (1-3): 191-207. - doi: 10.1016/j.foreco.2006.09.045

Samuelson L, Johnsen K, Stokes T (2004). Production, allocation, and stemwood growth efficiency of Pinus taeda L. stands in response to 6 years of intensive management. Forest Ecology and Management 192 (1): 59-70. - doi: 10.1016/ j.forec0.2004.01.005

Sanchez FG (2001). Loblolly pine needle decomposition and nutrient dynamics as affected by irrigation, fertilization, and substrate quality. Forest Ecology and Management 152 (1-3): 8596. - doi: 10.1016/S0378-1127(00)00592-2

Sayer EJ, Tanner EVJ, Cheesman AW (2006). Increased litterfall changes fine root distribution in a moist tropical forest. Plant and Soil 281 (12): 5-13. - doi: 10.1007/s11104-005-6334-X

Sayer EJ, Wright SJ, Tanner EVJ, Yavitt JB, Harms KE, Powers JS, Kaspari M, Garcia MN, Tuner BL (2012). Variable responses of lowland tropical forest nutrient status to fertilization and litter manipulation. Ecosystems 15 (3): 387-400. - doi: 10.1007/s10021-011-9516-9

Schumacher MV, Viera M, Witschoreck R (2008). Produção de serapilheira e transferência de nutrientes em área de segunda rotação com floresta de Pinus taeda L. no município de Cambará do Sul, RS. [Litter production and nutrients transfer in a second rotation area with $\mathrm{Pi}$ nus taeda L. forest in Cambará do Sul, RS]. Ciência Florestal 18 (4): 471-480. [in Portuguese] doi: $10.5902 / 19805098431$

Sun OJ, Payn TW (1999). Magnesium nutrition and photosynthesis in Pinus radiata: clonal variation and influence of potassium. Tree Physiology 19: 535-540. - doi: 10.1093/treephys/19.8.535 Trevisan E (1992). Classificação e caracterização de horizontes orgnicos sob povoamentos de Pinus taeda L. na região de Ponta Grossa - PR
[Classification and characterization of organic horizons under stands of Pinus taeda $L$. in the region of Ponta Grossa - PR]. Dissertação de Mestrado, Setor de Ciências Agrárias, Universidade Federal do Paraná, Curitiba, Brazil, pp. 106. [in Portuguese]

Vangelova EI, Hirano Y, Eldhuset TD, Sas-paszt L, Bakker MR, Püttsepp U, Brunner I, Lõhmus K, Godbold D (2007). Tree fine roots Ca/Al molar ratio - Indicator of $\mathrm{Al}$ and acidity stress. Plant Biosystems 141 (3): 460-480. - doi: 10.1080/1126 3500701626192

Vieira M, Schumacher MV (2009). Concentração e retranslocação de nutrientes em acículas de Pinus taeda L. [Concentration and retranslocation of nutrients in Pinus taeda L.] Ciência Florestal 19 (4): 375-382. [in Portuguese] - doi: 10.590 2/19805098893

Vogel JG, He D, Jokela EJ, Hockaday W, Schuur EAG (2015). The effect of fertilization levels and genetic deployment on the isotopic signature, constituents, and chemistry of soil organic carbon in managed loblolly pine (Pinus taeda L.) forests. Forest Ecology and Management 355: 91-100. - doi: 10.1016/j.foreco.2015.05.020

Yavitt JB, Harms KE, Garcia MN, Mirabello MJ, Wright SJ (2011). Soil fertility and fine root dynamics in response to 4 years of nutrient $(N, P$, K) fertilization in a lowland tropical moist forest, Panama. Austral Ecology 36 (4): 433-445. doi: 10.1111/j.1442-9993.2010.02157.x

Will GM (1978). Nutrient deficiencies in Pinus radiata in New Zealand. New Zealand Journal of Forestry Science 8 (1): 4-14. [online] URL: http:// www.scionresearch.com/_data/assets/pdf_file /0003/37182/NZJFS811978WILL4_14.pdf

Zhang D, Hui D, Luo Y, Zhou G (2008). Rates of litter decomposition in terrestrial ecosystems: global patterns and controlling factors. Journal of Plant Ecology 1 (2): 85-93. - doi: 10.1093/jpe/ rtnoo2

Zinn YL, Resck DVS, Silva JE (2002). Soil organic carbon as affected by afforestation with Eucalyptus and Pinus in the Cerrado region of Brazil. Forest Ecology and Management 166 (1/3): 285294. - doi: 10.1016/s0378-1127(01)00682-x

\section{Supplementary Material}

Tab. S1 - Mineral concentration (nutrients, $\mathrm{Al}$, and $\mathrm{Na}$ ) of forest floor fractions from a Pinus taeda L. stand subjected to fertilizer and lime treatments in Paraná state, southern Brazil.

Tab. S2 - Results of principal component analysis of litter layer elemental compositions and $\mathrm{C}: \mathrm{N}$ ratios for a Pinus taeda $\mathrm{L}$. stand subjected to fertilizer and lime treatments in Paraná state, southern Brazil.

Tab. S3 - Total nutrients (C, N, Ca, Mg, P, K, $\mathrm{Mn}$, and $\mathrm{Fe}$ ), $\mathrm{Al}$, and $\mathrm{Na}$ in forest floor litter layers (new litter, old litter, coarse fragmented layer, and fine fragmented layer) from a Pinus taeda L. stand subjected to fertilizer and lime treatments in Paraná state, southern Brazil.

Link: Adam_3626@supploo1.pdf 